\title{
Mercury Removal from Aqueous Solution by Mixed Mineral Systems II. The Role of Solution Composition and Ageing
}

\author{
D.E. Egirani ${ }^{1}$, A.R. Baker ${ }^{2}$ J.E. Andrews ${ }^{2}$ \\ ${ }^{1}$ Faculty of Science, Niger Delta University, Wilberforce Island, Nigeria \\ ${ }^{2}$ Schools of Environmental Sciences, University of East Anglia, Norwich, United Kingdom
}

\begin{abstract}
This study investigates $\mathrm{Hg}(\mathrm{II})$ removal onto binary mixed mineral sorbents from simulated mercury contaminated water, relevant to surface and groundwater impacted environment. However, sorption pattern appeared to be controlled by outer sphere complexation, inner sphere complexation and intra-particle diffusion for Hg (II) sorbed on goethite and mixed mineral system of goethite-montmorillonite with respect to $\mathrm{pH}$. Decrease in $\mathrm{Hg}$ (II) sorption as Cp was increased may be attributed to increase in particle size and aggregation of the mineral suspensions. The Cp effect is also related to effective surface area, pressure, and force at the mineral/water interface The complex behavior of mineral systems over the range of residence time investigated may be attributed to increased hydroxylation of the mineral surface resulting in the formation of new reactive sites.
\end{abstract}

Keywords: mercury, removal, reaction, kinetics, mixed mineral systems.

\section{Introduction}

Mercury is one of the most toxic elements in the aqueous environment [1] The health of top predators, e.g. birds, fish, seals, and man, is thereby threatened [2-3] Three forms of non-biodegradable mercury contaminant namely elemental mercury $(\mathrm{Hg} 0)$, oxidized mercury $\left(\mathrm{Hg}^{2+}\right)$ and particulate-bound mercury $(\mathrm{HgP})$ exist. The oxidized form of mercury is transformed into its toxic methylated species, transferred and bioamplified as monomethy 1 merury (MMHg) in the aquatic food chains [4-13]

The major sources of $\mathrm{Hg}$ emission worldwide comes from coal combustion and Au amalgamation [1416]. Alluvial $\mathrm{Au}$ mining activities, using elemental $\mathrm{Hg}$ for $\mathrm{Au}-\mathrm{Hg}$ amalgamation constitute biogeochemical reactors where dissolved organic matter (OM), $\mathrm{SO} 4$ and $\mathrm{Fe}$ oxides favor bacterial activity [17].

The release of mercury into bodies of water is increasing, and non-admissible level of greater than $1 \mu \mathrm{g} / \mathrm{L}$ are found in surface and groundwater [18]. Mercury is carcinogenic and its poisoning results in severe chronic disease or death [19]. In addition, elemental mercury exhibits high volatility and bioaccumulation in the environment and neurological health impact $[20,21]$. Specifically, methyl mercury induced by microbial biomethylation of mercuric ions $\left(\mathrm{Hg}^{2+}\right)$ can accumulate in the body and can cause brain damage and other chronic diseases [22-24]. Hence, testing the removal of $\mathrm{Hg}^{2+}$ from aqeous solution in the laboratory as a way of mimicking its removal from water bodies remains a current and relevant research topic.

The removal of dissolved mercury species can be hampered by the absence of reliable sorbents and solution chemistry. For $\mathrm{Hg} 0$ removal in liquid phase, the key point is to convert $\mathrm{Hg} 0$ to $\mathrm{Hg} 2+$ rapidly, the latter being easily dissolved in water as reported in literature [25-27]. The removal of mercury from contaminated water bodies is controlled by the solution composition and ageing [ 28, 29].

Solution $\mathrm{pH}$ controls (a) the solubilities of mercury species; (b) hydrolysis behavior of mercury ions; and (c) surface charge of clays and hydroxides. $\mathrm{pH}$ variability is known to affect the charge density on sorbents due to deprotonation of active sites [30,31].

Sorbate sorption may decrease as particle concentration increases (outer sphere complexation) or not be significantly affected as particle concentration increases (inner sphere complexation) [32]. Mercury uptake is associated with surface area availability and number of surface-active groups. Also, Increase in adsorption as particle concentration increases (promotive particle concentration effects) for organic and inorganic substances sorbed on colloidal clay and oxide particles still remains an area of research interest in conventional surface complexation theory [33-35].

Prolonging the residence time of solid mineral phase in the absence of a sorbate could results in much mineral surface reorganization. This is due to the fact that high and new reactive sites are formed. Mercury sorption by porous sorbents is known to exhibit variable behavior over time [36- 38].

\subsection{Theoretical models and isotherms}

To addresses the suitability of mixed mineral suspensions of clay and (hydr)oxides for $\mathrm{Hg}$ (II) removal, a theory derived from Freundlich isotherm model is designed to explain the predicted behavior of mineral- 
arsenite interactions as influenced by extraneous factors of $\mathrm{pH}$, solid concentration and residence time or ageing [39].

Detailed system characterization and an empirical model involving the distribution coefficient $(\mathrm{Kd})$ as used in previous paper [40-41]. \% sorption used in calculating $\mathrm{Hg}(\mathrm{II})$ sorbed is provided [42-45]

$\% \operatorname{Hg}(\mathrm{II})$ sorbed $=\frac{\left(C_{i}-C_{e}\right)}{C_{i}} \times 100 \%$

where $C_{i}$ and $C_{e}$ are the initial and equilibrium $\operatorname{Hg}(\mathrm{II})$ concentrations in mg/L,

Distribution coefficient used in calculating $\mathrm{Hg}(\mathrm{II})$ sorbed was derived from the Freundlich model equation,

$S=K d C^{N}$

2

where $\mathrm{S}$ is the sorbed concentration $(\mu \mathrm{g} / \mathrm{kg}), \mathrm{Kd}$ is the distribution coefficient, $\mathrm{C}$ is the equilibrium concentration $(\mu \mathrm{g} / \mathrm{g})$, and $\mathrm{N}=1$ is a chemical-specific coefficient derived from the slope of the plot. The empirical model as provided [40] to address the mineral-Hg interactions is given:

$\mathrm{Hg}$ (II) sorbed difference $=\mathrm{Hg}$ (II) sorbed- $\mathrm{Hg}$ (II) sorbed $_{\text {total }}$

$\operatorname{Hg}$ (II) sorbed $_{\text {total }}=\frac{\left(S_{1}+S_{2}+S_{n}\right)}{n}$

where $\mathrm{Hg}$ sorbed $_{\text {total }}$ is the theoretical sorption for a 1:1 mixed mineral suspension, $\mathrm{S}_{1}$ is the $\mathrm{Hg}$ (II) sorbed on first single mineral suspension, and $S_{2}$ is the $\mathrm{Hg}$ (II) sorbed on second single mineral suspension, $\mathrm{S}_{\mathrm{n}}$ is the $\mathrm{Hg}$ (II) sorbed on $\mathrm{n}$ number of mineral suspensions and $\mathrm{n}$ is the number of mineral suspensions.

The simple empirical model used for the partitioning of a sorbed mercury contaminant between single mineral phases and mixed mineral phases is based on the assumptions that the following could account for differences between single and mixed mineral sorption:

1. Secondary mineral phase developed during sorbate-sorbent interaction .

2. Components of minerals in the mixed mineral suspension acted as chemisorbed species and not as individual networks.

3. differential mass of mixed and single mineral phases.

The difference between the actual sorption and the theoretical sorption was used to clarify the effects of mineral mixing on $\mathrm{Hg}$ (II) sorption. Mineral mixing is said to (a) enhance $\mathrm{Hg}$ (II) removal where the difference is positive; (b) depresses or attenuate $\mathrm{Hg}(\mathrm{II})$ removal where the difference is negative; and (c) have no effect on $\mathrm{Hg}$ (II) removal where no difference exist between $\mathrm{Hg}$ (II) sorbed and theoretical $\mathrm{Hg}$ (II) sorption.

Currently available technologies for the treatment of mercury-polluted aqueous solutions include precipitation, membrane filtration, ion exchange, electrodeposition, adsorption and coagulation [46-47]. Other researches focused on the removal of $\mathrm{Hg}(\mathrm{II})$ from water by sorption processes are provided [48- 50] . However, the use of mixed mineral systems of clays and hydroxides as suitable sorbents in mercury removal is lacking in literature. Therefore, this paper addresses the sorption relationship between simulated mercury contaminated water and mixed mineral phases of kaolinite/montmorillonite, kaolinite/goethite and montmorillonite/goethite. This is based on different solution composition such as $\mathrm{pH}$, solid concentration and residence time (ageing).

\subsection{Sorption experiments}

\section{Experimental methods}

Batch mode experiments in this study were conducted using single mineral suspensions of kaolinite, montmorillonite and goethite. Also, 1:1 mixed mineral suspensions of kaolinite/montmorillonite, kaolinite/goethite and montmorillonite/goethite were used to elucidate the differences in sorption behaviour between the single and mixed mineral phases. Characterization of sorbents used in this study included (a) particle size; (b) $\mathrm{pH}$ and (c) specific surface area (SSA) and details provided elsewhere [41-42].

For batch mode $\mathrm{pH}$ investigation, single and 1:1 mixed mineral suspensions made up to $50 \mathrm{ml}$ containing $1 \%$ (by mass) mineral suspension were reacted with solution containing $10 \mathrm{ppm}$ of mercury at zero electrolyte background. Treated suspension was adjusted to the required $\mathrm{pH}$ (ranging from $\mathrm{pH} 4$ to 8 ) using $0.1 \mathrm{M} \mathrm{HNO3}$ and $0.1 \mathrm{M} \mathrm{NaOH}$. The treated suspensions were equilibrated for $24 \mathrm{~h}$ and $\mathrm{pH}$ measured using a Model 3340 Jenway ion meter.

For batch mode solid or particle concentration investigation, single and 1:1 mixed mineral suspensions were made up to $50 \mathrm{ml}$ containing solid concentrations $(\mathrm{g} / \mathrm{1})$ of $2,4,6,8$ and 10 were reacted with solution containing $10 \mathrm{ppm}$ of mercury at zero electrolyte background. The treated suspensions were adjusted to $\mathrm{pH} 4$ and equilibrated for $24 \mathrm{~h}$.

Batch mode ageing investigations was carried out from 24 to $720 \mathrm{~h}$ using single and 1:1 aged mixed mineral suspensions containing $1 \%$ (by mass were reacted with solution containing $10 \mathrm{ppm}$ of $\mathrm{Hg}$ (II) at zero 
electrolyte background. The treated suspensions, adjusted to $\mathrm{pH} 4$ with no added electrolyte, were equilibrated for $24 \mathrm{~h}$.

Mercuric chloride $\left(\mathrm{HgCl}_{2}\right)$ provided by Iconofile Company Inc was employed as the source of $\mathrm{Hg}(\mathrm{II})$. .A standard solution containing variable concentrations of $\mathrm{Hg}(\mathrm{II})$ in ppm was prepared by dissolving $\mathrm{HgCl}_{2}$ (Merck) in distilled water. In all experimental studies conducted in triplicates, samples were stored in the dark at room temperature $\left(23 \pm 3{ }^{\circ} \mathrm{C}\right)$ not exceeding $24 \mathrm{~h}$ before analysis [51]. Supernatant was filtered through a cellulose acetate filter (pore size $0.2 \mu \mathrm{m}$ ) and analyzed for $\mathrm{Hg}$ (II) using a Hitachi Atomic Absorption Spectrophotometer (HG-AAS).

\section{Results and discussion}

\subsection{Mixed mineral suspensions and $\mathrm{pH}$ effects on $\mathrm{Hg}$ (II) removal}

$\mathrm{Hg}(\mathrm{II})$ demonstrated a linear sorption increase with increasing $\mathrm{pH}$ for single mineral suspensions of kaolinite, montmorillonite, mixed mineral suspensions of kaolinite-montmorillonite and Goethite-Kaolinite (Fig.1 and Fig 2). The behavior of kaolinite and mixed mineral systems containing kaolinite demonstrated a linear behaviour in $\mathrm{Hg}$ (II) removal. Goethite and goethite/montmorillonite demonstrated a stepwise decrease in $\mathrm{Hg}(\mathrm{II})$ sorption as $\mathrm{pH}$ was increased. $\mathrm{Hg}(\mathrm{II})$ sorption by goethite -montmorillonite decreased between $\mathrm{pH} 4$ and $\mathrm{pH} 5$, changing slope and dipping up to $\mathrm{pH} 7$ before increasing over the remaining range of $\mathrm{pH}$. This variability in sorption may be attributed to increased deprotonation of reactive sites as $\mathrm{pH}$ was increased. However, sorption pattern appeared to be controlled by outer sphere complexation, inner sphere complexation and intraparticle diffusion for $\mathrm{Hg}(\mathrm{II})$ sorbed on goethite and mixed mineral system of goethite-montmorillonite with respect to $\mathrm{pH}$.

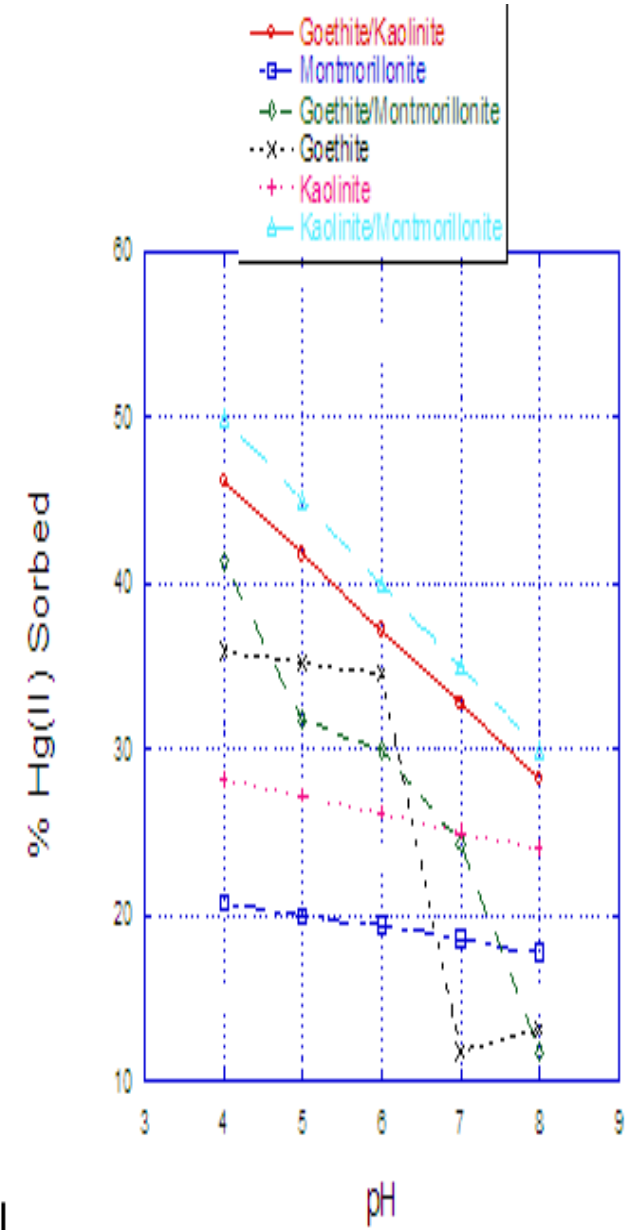

Figure 1: Plots of $\% \mathrm{Hg}(\mathrm{II})$ sorbed versus $\mathrm{pH}$ sorption difference vs, $\mathrm{pH}$ for $\mathrm{Hg}(\mathrm{II})$ sorbed single and mixed mineral systems

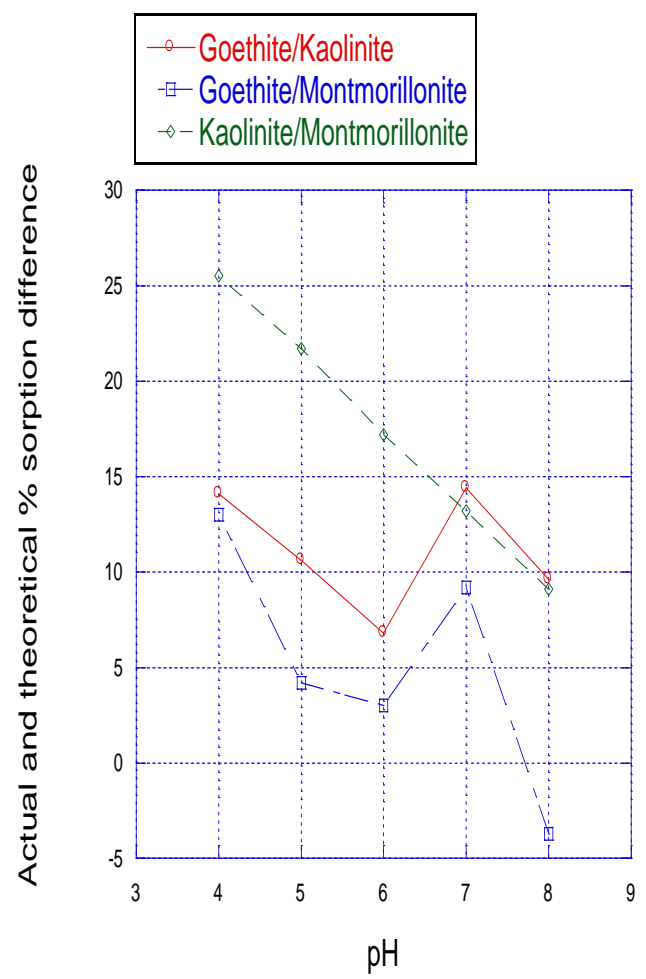

Figure 2: Plots of actual and theoretical \% for single and mixed mineral systems for on mixed mineral systems 


\subsection{Mixed mineral suspensions and Cp effects on $\mathrm{Hg}(\mathrm{II})$ removal}

Changes in $\mathrm{Hg}(\mathrm{II})$ sorption as particle concentration $(\mathrm{Cp})$ increased, exhibiting a linear decrease of $\mathrm{Hg}$ (II) sorbed on kaolinite/goethite, kaolinite-montmorillonite goethite-montmorillonite and montmorillonite over the range of $\mathrm{pH}$ investigated. Kaolinite demonstrated an increase in $\mathrm{Hg}$ (II) sorption as particle concentration was increased. Goethite exhibited a sinusoidal behavior, decreasing up to $0.004 \mathrm{~g} / \mathrm{L}$ in $\mathrm{Hg}$ (II) sorption, then increasing up to $0.008 \mathrm{~g} / \mathrm{L}$ (Fig.3 and Fig 4). The behavior of montmorillonite containing aluminium and mixed mineral phases containing Al-montmorillonite may form separate (discrete) particles or it may form coatings on other mineral surfaces. Coatings of only a few atomic layers thickness are sufficient to influence sorption rates and behaviour [52]. This may account for differences in sorption behavior for $\mathrm{Hg}(\mathrm{II})$ sorbed on mixed mineral suspensions containing montmorillonite.

Decrease in $\mathrm{Hg}(\mathrm{II})$ sorption as $\mathrm{Cp}$ was increased may be attributed to increase in particle size and aggregation of the mineral suspensions. The $\mathrm{Cp}$ effect is also related to effective surface area, pressure, and force at the mineral/water interface [Matis et al 1999]. Increase in Cp results in low pressure at the interface and a subsequent decrease in sorbing ion diffusion to reactive sites [32, 34]. Increase in $\mathrm{Hg}(\mathrm{II})$ uptake over the range of Cp investigated could also be attributed to the increased clays and hydroxide(s) surface area available for contact with the $\mathrm{Hg}(\mathrm{II})$ leading to increased number of surface-active groups.

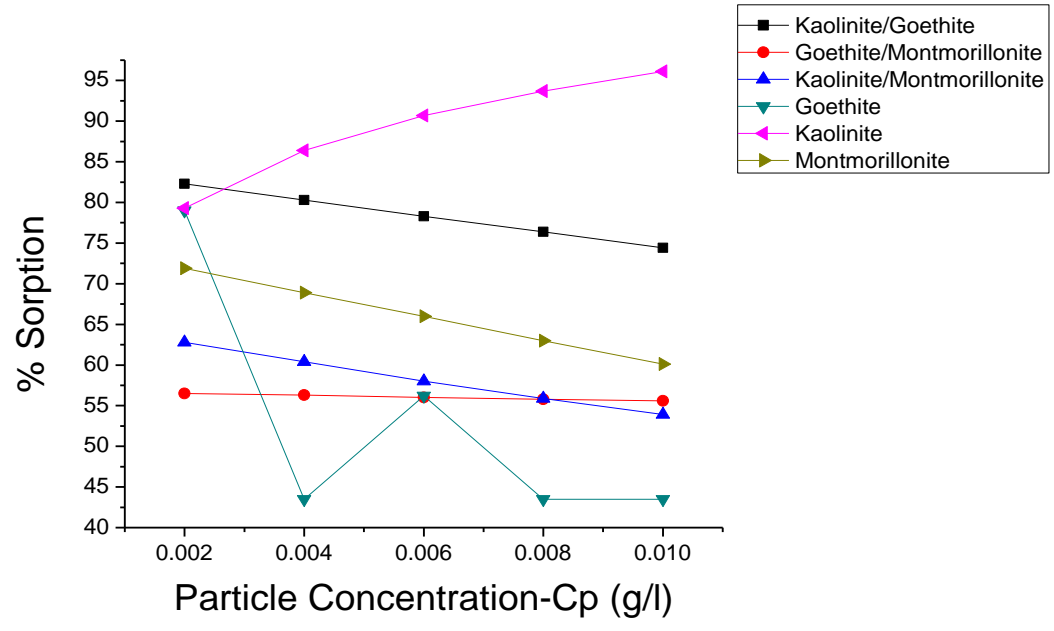

Figure 3: Plots of $\mathbf{H g}(\mathrm{II})$ sorbed versus particle concentration for single and mixed mineral systems $\mathrm{Hg}(\mathrm{II})$ sorbed difference (i.e., $\mathrm{Hg}$ (II) sorption obtained by experiments) and theoretical $\mathrm{Hg}(\mathrm{II})$ sorption (i.e., the predicted arsenite sorption obtained from the average summation of $\mathrm{Hg}$ (II) sorbed on the single mineral suspensions used in the mixing experiments) exhibited positive sorption differences for kaolinite/goethite over the $\mathrm{Cp}$ range investigated. This means that mineral mixing decreased ( $\mathrm{Hg}(\mathrm{II})$ sorption for kaolinite/goethite. On the other hand, sorption differences started on a negative territory and exhibited a step-wise increase for goethite/montmorillonite, becoming positive as Cp increased to $0.01 \mathrm{~g} / \mathrm{L}$ (Fig.3). This means that mineral mixing based on the empirical model, reduced $\mathrm{Hg}$ (II) sorption at the onset and increased $\mathrm{Hg}$ (II) removal as the $\mathrm{Cp}$ was increased for goethite/montmorillonite. However, differences in actual and theoretical sorption for $\mathrm{Hg}$ (II) sorbed on kaolinite/montmorillonite exhibited a decrease as $\mathrm{Cp}$ was increased. This decrease was on the negative territory indicating that mineral mixing reduced $\mathrm{Hg}$ (II) uptake for this mixed mineral phase [53].
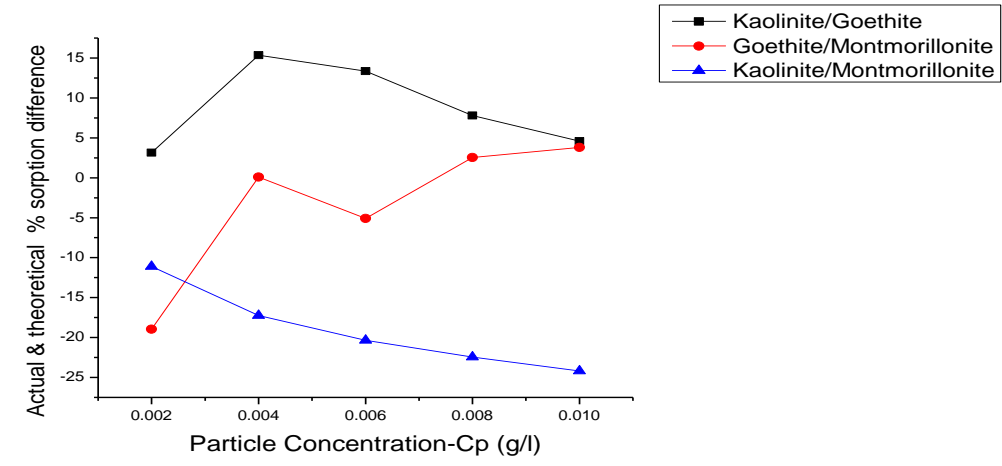

_ Kaolinite/Montmorillonite

Fig. 4: Plots of actual and theoretical sorption differences versus particle concentration for $\mathbf{H g}$ (II) sorbed on mixed mineral systems 


\subsection{Mixed mineral suspensions and ageing effects on Hg (II) removal}

All single and mixed mineral systems exhibited a near linear decrease in $\mathrm{Hg}$ (II) sorption over the range of residence time investigated (Figure 5 and Fig 6). The order of $\mathrm{Hg}$ (II) sorption on the mineral phases is in the order goethite> goethite-kaolinite>montmorillonite>goethite-montmorillonite>kaolite-montmorillonite> kaolinite. Goethite/montmorillonite exhibited a cross-over sorption with kaolinite/montmorillonite at 432 hours contact time. This means that $\mathrm{Hg}$ (II) uptake for these two mixed mineral phases are the same at this residence time.

Differences in actual and theoretical \% sorption exhibited a linear increase all in the negative territory for kaolinite-montmorillonite and goethite-montmorillonite. This may suggest a decrease in $\mathrm{Hg}$ (II) removal due to mineral mixing for these two mixed mineral systems. The sinusoidal and non-linear pattern of sorption for goethite-kaolinite beginning in the positive territory and ending in the negative territory suggest that $\mathrm{Hg}$ (II) sorption for this mixed mineral phase implies that mercury sorption onto goethite-kaolinite is not strictly a surface phenomenon [32]. $\mathrm{Hg}$ (II) step-wise sorption probably indicated reaction phases attributed to outer sphere, inner sphere complexation and intra-particle diffusion as reported elsewhere [40-41]..Increase in $\mathrm{Hg}(\mathrm{II})$ sorption as residence time increased between 432 and 476 hours of contact for goethite-kaolinite may be attributed to increased hydroxylation of the mineral surfaces, resulting in the formation of new reactive sites [54]

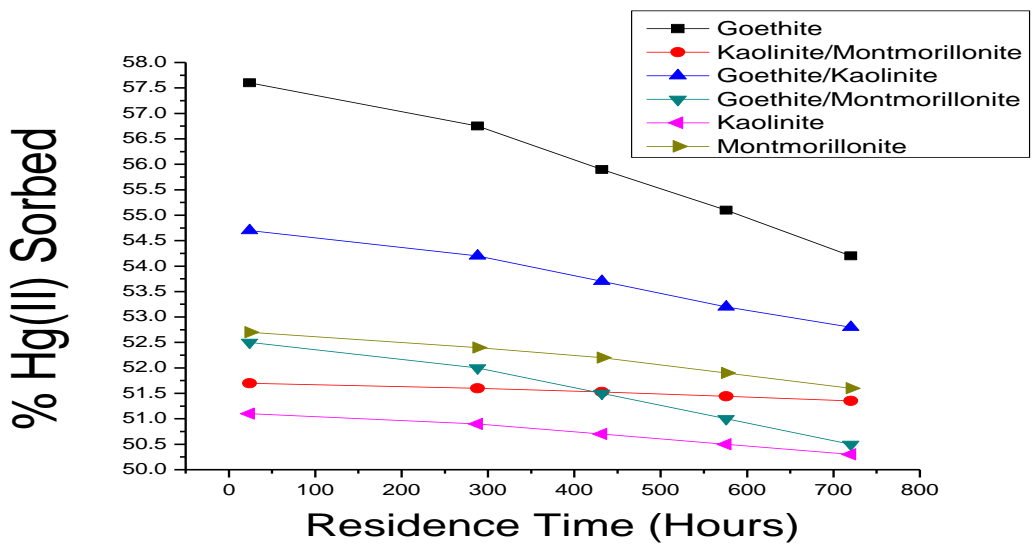

Fig. 5: Plots of \% $\mathrm{Hg}$ (II) sorbed versus residence time for single and mixed mineral systems

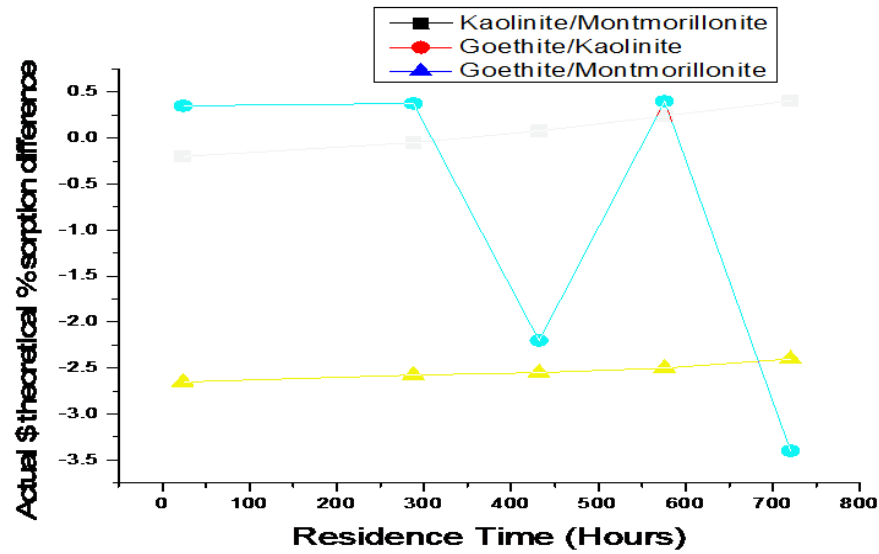

Figure 6: Plot of actual and theoretical \% sorption difference vs. residence time for $\mathrm{Hg}$ (II) sorbed on mixed mineral systems

\section{Conclusions}

The possibilities of using mixed mineral phases of kaolinite, montmorillonite, and goethite to remove $\mathrm{Hg}(\mathrm{II})$ from Simulated contaminated surface and ground water has been investigated as a function of solution composition and ageing. Variability in $\mathrm{Hg}$ (II) sorption exist over the range of $\mathrm{pH}$ investigated. The behavior of kaolinite and mixed mineral systems containing kaolinite demonstrated a linear behaviour in $\mathrm{Hg}(\mathrm{II})$ removal. 
Goethite and goethite/montmorillonite demonstrated a stepwise decrease in $\mathrm{Hg}(\mathrm{II})$ sorption as $\mathrm{pH}$ increases. This variability in sorption may be attributed to increased deprotonation of reactive sites as $\mathrm{pH}$ was increased. Sorption pattern appeared to be controlled by outer sphere complexation, inner sphere complexation and intraparticle diffusion for $\mathrm{Hg}(\mathrm{II})$ sorption some of the mineral phases.

Changes in $\mathrm{Hg}(\mathrm{II})$ sorption as particle concentration (Cp) increased, exhibiting a linear decrease of $\mathrm{Hg}$ (II) sorbed on kaolinite/goethite, kaolinite-montmorillonite goethite-montmorillonite and montmorillonite over the range of $\mathrm{pH}$ investigated. However, differences in actual and theoretical sorption for $\mathrm{Hg}$ (II) sorbed on kaolinite/montmorillonite exhibited a decrease as $\mathrm{Cp}$ was increased. This decrease was on the negative territory indicating that mineral mixing reduced $\mathrm{Hg}(\mathrm{II})$ uptake for this mixed mineral phase.

All single and mixed mineral systems exhibited a near linear decrease in $\mathrm{Hg}(\mathrm{II})$ sorption over the range of residence time investigated. $\mathrm{Hg}(\mathrm{II})$ step-wise sorption probably indicated reaction phases attributed to outer sphere, inner sphere complexation and intra-particle diffusion. The variable and complex behavior of mineral systems over the range of residence time investigated may be attributed to increased hydroxylation of the mineral surface resulting in the formation of new reactive sites.

\section{References}

[1]. Quig, D. 1998, Cysteine toxity and metal toxicity, Altern Med Rev 3, 262-270.

[2]. Braune, B Muir, D DeMarch, B Gamberg, M Poole, K Currie R, Dodd, M Duschenko, W Eamer, J Elkin, B Evans, M Grundy, S Hebert, C Johnstone, R Kidd, K Koenig, B Lockhart, L Marshall, H Reimer, K Sanderson J 1999, Spatial and temporal trends of contaminants in Canadian Arctic freshwater and terrestrial ecosystems: a review 145-207. Total Environ. 230, 145-207.

[3]. Muir, D Braune, B DeMarch, B Norstrom, R Wagemann, R Lockhart, L Hargrave, B Bright, D Addison, R Payne, J Reimer K., 1999, Spatial and temporal trends and effects of contaminants in the Canadian Arctic marine ecosystem: a review, 230, 83-144.

[4]. Trasande L, Landrigan P.J, Schechter C. 2005, Public health and economic consequences of methyl Hg toxicity to the developing brain, Environ Health Perspect;113:590-6.

[5]. $\quad$ Akagi, H., Malm, O., Branches, F.G.P., Kinjo, Y., Kashima, Y., Guimara, J.R.D., Oliveira, R.B., Haraguchi, K., Pfeiffer, W.C., Takizava, Y. 1995. Human exposure to mercury due to goldmining in the Tapajos river basin, Amazon, Brazil: speciation of mercury in human hair, blood and urine. Water Air Soil Pollut. 80, 85-94.

[6]. Boudou, A., Maury-Brachet, R., Coquery, M., Durrieu, G., Cossa, D., 2005. Synergic effect of gold mining and damming on mercury contamination in fish. Environ Sci. Technol. 39, 2448-2454.

[7]. Carmouze, J.P., Lucotte, M., Boudou, A., 2001. Mercury in the Amazon. Human and Environmental Implications, Health Risks. IRD editions, Bondy, p. 20.

[8]. Dolbec, J., Mergler, D., Sousa Passos, C.J., Sousa de Morais, S., Lebel, J., 2000. Methylmercury exposure affects motor performance of a riverine population of the Tapajos river, Brazilian Amazon. Int. Arch. Occup. Environ. Health 73, 195-203.

[9]. Frery, N., Maury-Brachet, R., Maillot, E., Deheeger, M., Merona de, B., Boudou, A., 2001, Goldmining activities and mercury contamination of native Amerindian communities in French Guiana: key role of fish in dietary uptake. Environ Health Perspect. 109, 449-456.

[10]. Pfeiffer, W.C., Lacerda, L.D., Salomon, W., Malm, O., 1993, Environmental fate of mercury from gold mining in the Brazilian Amazon. Environ. Rev. 1, 26-37.

[11]. Veiga, M. M, P. Maxson, and L.D. Hylander 2006, Origin of mercury in artisanal and small-scale gold mining. J. of Cleaner Production. 14: 436-447.

[12]. Watras, C., 1992, . Mercury and methylmercury in individual zooplankton: implications for bioaccumulation. Limnol. Oceanogr. 37, 1313-1318.

[13]. Lee S, Park Y. 2003, Gas-phase mercury removal by carbon-based sorbents. Fuel Process Technol; 84(1-3):197-206

[14]. Jaffe, D. Strode, S. 2008, Sources, fate, and transport of atmospheric mercury from Asia, Environmental Chemistry $5121-126$

[15]. UNEP, 2008, in: Global Atmospheric Mercury Assessment: Sources, Emissions and Transport, UNEP Chemicals Branch, Geneva, p. 42.

[16]. Wu, Y. Wang, S.. Streets, D.G Hao, J. Chan, M. Jiang, J. 2006, Trends in anthropogenic mercury emissions in China from 1995 to 2003, Environmental Science and Technology 40, 5312-5318.

[17]. Muresan B. Pernet-Coudrier B. Cossa D. Varrault G. 2011, Measurement and modeling of mercury complexation by dissolved organic matter isolates from freshwater and effluents of a major wastewater treatment plant Applied Geochemistry 26, 2057-2063.

[18]. USEPA 2001, National Primary Drinking Water Regulations; Arsenic and Clarifications to Compliance and New Source Contaminants Monitoring, Washington, DC.

[19]. Langford, N.; Ferner, R. 1999, Mercury from chlor-alkali plants: measured concentrations in food product sugar J. Hum. Hypertens. 13, 651-656.

[20]. Pavlish J.H, Holmes M.J, Benson S.A, Crocker C.R, Galbreath K.C. 2004, Application of sorbents for mercury control for utilities burning lignite coal. Fuel Process Technol; 85:563-76.

[21]. Dastoora AP, Larocpue Y. 2004, Global circulation of atmospheric mercury: a modeling study, Atmos Environ 38:147-61.

[22]. Qu, R. Liu, J. Sun, C. Zhang, Y.. Ji, C Yin, P. 2010, Removal and separation of $\mathrm{Hg}(\mathrm{II})$ ions from aqueous solutions by macroporous polystyrene-co-divinylbenzenesupported polyamine chelating resins, J. Chem. Eng. Data 55, 4650-4659.

[23]. Wang J. Zhang Y. Han L. Chang L. Bao W. 2013, Simultaneous removal of hydrogen sulfide and mercury from simulated syngas by iron-based sorbents Fuel 103, 73-79.

[24]. 265, 552-557.

[25]. Pacyna, E.G Pacyna, J.M. 2002, Global emission of mercury from anthropogenic sources in 1995, Water Air Soil Pollut. 137, 149165.

[26]. Ye, Q.F. Wang, C.Y. Wang, D.H. Sun, G. Xu, X.H. 2006, Hg0 absorption in potassium persulfate solution, Journal of Zheijang University Science B - Biomedicine \& Biotechnology 7 (5) 404-410.

[27]. Xu, X.H. Ye, Q.F. Tang, T.M. Wang D.H., 2008, $\mathrm{Hg} 0$ oxidative absorption by $\mathrm{K}_{2} \mathrm{~S}_{2} \mathrm{O}_{8}$ solution catalyzed by $\mathrm{Ag}+\mathrm{And} \mathrm{Cu} 2+$, Journal of Hazardous Materials 158 410-416. 
[28]. Cen, K.F. 2001, Technical report of clean coal fired power generation, in: 2nd seminar for the clean coal technology of China coal society, Hangzhou, 12-18,

[29]. Deshicar, A.M.. Bokade, S.S Dara, S.S. 1990, Modified hardwickia binata bark for adsorption of mercury (II) from water, Water Res. 24, 1011-1016

[30]. McBride M.B. 1982, Organic anions adsorption on aluminum hydroxides: spin probe studies,. Clay and clay minerals, 30(4), 438444.

[31]. Goksungur, Y. Uren, S. Guvenc, U. 2005, Biosorption of cadmium and lead ions by ethanol treated waste baker's yeast biomass, Bioresource Technol. 96, 103-109.

[32]. Holan, Z.R. Volesky, B. 1994, Biosorption of lead and nickel by biomass of marine algae, Biotechnol. Bioengery 43, $1001-1009$.

[33]. Akar, T. Kaynak, Z. . Ulusoy, S Yuvaci, D. Ozsari, G. Akar, S.T. 2009, Enhanced biosorption of nickel(II) ions by silica-gelimmobilized waste biomass: biosorption characteristics in batch and dynamic flow mode, J. Hazard. Mater. 163, $1134-1141$.

[34]. Shao, W. Chen, L.. Lu, L Luo, F. 2011, Removal of lead (II) from aqueous solution by a new biosorption material by immobilizing Cyanex272 in cornstalks, Desalination 265, 177-183.

[35]. Dzombak, D.A. Morel, F. 1990, Surface Complexation Modeling: Hydrous Ferric Oxide, Wiley, New Y ork, p. 20.

[36]. Lutzenkirchen, J 2001, Ionic Strength Effects on Cation Sorption to Oxides: Macroscopic Observations and Their Significance in Microscopic Interpretation J. Colloid Interface Sci. 65, 149-155.

[37]. Devotta, I. Mashelkar, R.A. 1996, Competitive diffusion-adsorption of polymers of differing chain lengths on solid surfaces, Chem. Eng. Sci. 51, 561-569.

[38]. Matis, K. A, Lehmann, M., \& Zouboulis, A. I 1999, Modeling sorption of metals from aqueous solution onto mineral particles: The case of arsenic ions and goethite ore. In P. Misaelides, F. Macašek, T. J. Pinnavaia, \& C. Colella (Eds.), Natural microporou s materials in environmental technology (pp. 463-472). The Netherlands: Kluwer.

[39]. Hatje, V.H. Hill, D.M. McOrist, G. Birch, G.F. Szymczak, R. 2003, Kinetics of trace element uptake and release by particles in estuarine waters: effects of pH, salinity, and particle loadin J. Environ. Int. 29, 613-618.

[40]. Egirani DE, Baker AR, Andrews JE 2005a, Copper and zinc removal from aqueous solution by mixed mineral systems I: Reactivity and removal kinetics Journal of Colloid and Interface Science 291, 319-325. Egirani DE, Baker AR, Andrews JE 2005b, Copper and zinc removal from aqueous solution by mixed mineral systems II: The role of solution composition and aging. Journal of Colloid and Interface Science 291, 326-333.

[41]. Egirani DE, Baker AR, Andrews JE 2005b, Copper and zinc removal from aqueous solution by mixed mineral systems II: The role of solution composition and aging. Journal of Colloid and Interface Science 291, 326-333.

[42]. Altun, T., \& Pehlivan, E. 2012, Removal of Cr(VI) from aqueous solutions by modified walnut shells. Food Chemistry, 132, 693700 .

[43]. Giles D. E Mohapatra M. Issa T. B Anand S. Singh P. 2013, Iron and aluminium based adsorption strategies for removing arsenic from water Journal of Colloid and Interface Science 392, 311-318.

[44]. Al-Degs, Y.S. Tutunji, M.F. Baker, H.M 2003, Isothermal and kinetic adsorption behaviour of Pb" ions on natural silicate minerals. J. Clay Miner. 38, 501-509.

[45]. Horsfall Jnr. M and Spiff, A 2005, Effect of metal ion concentration on the biosorption of Pb2+ and Cd2+ by Caladium bicolor (wild cocoyam), African Journal of Biotechnology 4 (2), 191-196.

[46]. Aguado, J Arsuaga, . J.M Arencibia,. A. 2008, Aqueous heavy metals removal by adsorption on amine-functionalized mesoporous silica Micropor. Mesopor. Mater. 109, 513-524.

[47]. Vieira, R.S. Guibal, E. Silva, E.A. Beppu, M.M. 2007, adsorption and desorption of binary mixtuires of copper and mercury ions on natural and crossedlinked chitosan membranes, Adsorption 13,603-611.

[48]. Zhang, F.-S Nriagu, J.O. Itoh, H. 2005, Mercury removal from water using activated carbons derived from organic sewage sludge, Water Res. 39, 389-395.

[49]. Mibeck, B.A.F. Olson, E.S. Miller, S.J. 2009, $\mathrm{HgCl} 2$ sorption on lignite activated carbon: analysis of fixed-bed results, Fuel Process. Technol. 90, 1364-1371.

[50]. Kim, E.-A. Seyfferth, A.L. Fendorf, S. Luthy, R.G. 2011, Immobilization of Hg(II) in water with polysulfide-rubber (PSR) polymer-coated activated carbon, Water Res. 45 453-460.

[51]. Morton J.D Semaru J.D. Hayes K.F. 2001, An X-ray absorption spectroscopy study of the structure and reversibility of copper adsorbed to montmorillonite clay, Geochim. Cosmochim. Acta 65, 2709-2722.

[52]. Cataldo S., Gianguzza A.,, Pettignano A., Villaescusa I., 2013, Mercury(II) removal from aqueous solution by sorption onto alginate, pectate and polygalacturonate calcium gel beads. A kinetic and speciation based equilibrium study, Reactive \& Functional Polymers 73 207-217.

[53]. Appel C, Ma L 2002, Concentration, pH, and surface charge effects on. Cd and Pb sorption in tropical soils. J. Environ. Qual., 31: 581-589.

[54]. Schlegel M. L., Manceau A., Charlet L, Chateigner D., Hazemann J.-L., 2001, Sorption of metal ions on clay minerals. III. Nucleation and epitaxial growth of $\mathrm{Zn}$ on the edges of hectorite. Geochimica et Cosmochimica Acta 65, 4155-4170. 